\title{
PERAN BALAI PERLINDUNGAN DAN REHABILITASI SOSIAL WANITA (BPRSW) YOGYAKARTA DALAM MENANGANI WANITA RAWAN SOSIAL EKONOMI
}

\author{
Oleh: \\ Noor Yuli Astuti, Poerwanti Hadi Pratiwi dan Aris Martiana \\ Pendidikan Sosiologi, Fakultas IImu Sosial, Universitas Negeri Yogyakarta \\ Email : astutinooryuli@yahoo.com
}

\begin{abstract}
Abstrak
Penelitian ini mendeskripsikan peran Balai Perlindungan dan Rehabilitasi Sosial Wanita Yogyakarta dalam menangani WRSE beserta faktor pendorong dan faktor penghambat yang dihadapi. Penelitian ini merupakan penelitian kualitatif deskriptif. Hasil penelitian menunjukkan bahwa peran BPRSW Yogyakarta dalam menangani WRSE dilakukan dengan memberikan perlindungan sosial dan rehabilitasi sosial. Perlindungan sosial dilakukan dengan mempertimbangkan siapa yang boleh berkunjung, pembatasan jam kunjung, penentuan tempat kunjung, kontrol dalam penggunaan HP dan kerahasiaan identitas WRSE. Peran dalam rehabilitasi sosial diwujudkan dalam bimbingan fisik, mental, sosial dan keterampilan. Setelah selesai mendapatkan bimbingan tersebut WRSE akan melakukan PBK (Praktek Belajar Kerja). BPRSW Yogyakarta memiliki program bimbingan lanjut yaitu program sertifikasi bagi alumni BPRSW Yogyakarta. Faktor pendorong dalam menangani WRSE yaitu adanya sarana prasarana yang memadai, kinerja pekerja sosial yang baik dan adanya kerjasama dengan instansi lainnya. Sedangkan faktor penghambatnya yaitu terbatasnya jumlah anggaran, kurangnya jumlah pekerja sosial, kurangnya minat dan konsentrasi WRSE, WRSE memiliki suasana hati yang tidak stabil dan kurangnya dukungan dari keluarga dan masyarakat
\end{abstract}

Kata Kunci: Peran, Perlindungan dan Rehabilitasi Sosial, Wanita Rawan Sosial Ekonomi

\begin{abstract}
This research describe The Role of Woman Protection and Social Rehabilitation House Yogyakarta in handling WRSE along with the driving factors and inhibiting factor. This research was a descriptive qualitative research. The resultof this research shows that the role of BPRSW Yogyakart ain handling WRSE is done by providing social protection and social rehabilitation. Social protection is done by considering who may visit, limiting visiting hours, determining the place visit, controlling theuse of handphone and confidentiality of WRSE identity. The roles in social rehabilitation are manifested in physical, mental, social and skills guidance. After completing the guidance, WRSE will conduct PBK (Praktek Belajar Kerja). BPRSW Yogyakarta has an advanced guidance program, namely a certification program for BPRSW Yogyakarta's alumni. The driving factor in handling WRSE is the existence of adequate infrastructure, the perfomance of good social workers and cooperation with other instances. While the inhibiting factor arethe limited budget amount, lack of social workers, lack of interest and concentration in WRSE, WRSE has an unstable mood and lack of the support from family and society. Keywords: Role, Protection and Social Rehabilitation, Socio-Economic Vulnerable Woman
\end{abstract}

Peran Balai Perlindungan Wanita dan Rehabilitasi Sosial Wanita (BPRSW) Yogyakarta Dalam Menangani Wanita Rawan Sosial Ekonomi | Noor Yuli Astuti, Poerwanti Hadi 


\section{Pendahuluan}

Manusia sering disebut sebagai makhluk sosial yang tidak bisa hidup sendiri dan selalu membutuhkan bantuan dari manusia lainnya untuk memenuhi kebutuhan hidupnya. Seseorang akan berusaha semaksimal mungkin untuk bisa memenuhi kebutuhan hidupnya dengan harapan dapat hidup sejahtera. Tidak bisa dipungkiri bahwa kehidupan yang sejahtera merupakan impian dan dambaan dari setiap manusia yang ada di dunia ini. Bahkan dalam peraturan perundang-undangan juga menyebutkan bahwa setiap warga negara memiliki hak untuk memiliki kehidupan yang sejahtera.

Kesejahteraan sosial yaitu suatu kondisi terpenuhinya seluruh kebutuhan hidup masyarakat baik itu secara jasmani, rohani maupun sosial. Kesejahteraan sosial dapat terwujud apabila permasalahan sosial dapat teratasi dengan baik. Sayangnya, beberapa permasalahan sosial saat ini masih saja menyelimuti kehidupan masyarakat yang menyebabkan sebagian masyarakat belum mampu mencapai kehidupan yang sejahtera. Masyarakat yang memiliki permasalahan dalam pencapaian kesejateraan sosial dapat disebut dengan penyandang masalah kesejahteraan sosial (PMKS). Menurut UU RI No 11 tahun 2009 tentang Kesejahteraan Sosial menjelaskan bahwa kesejahteraan sosial merupakan kondisi terpenuhinya kebutuhan material, spiritual dan sosial warga negara agar dapat hidup layak dan mampu mengembangkan diri sehingga dapat melaksanakan fungsi sosialnya.

Daerah Istimewa Yogyakarta merupakan salah satu wilayah yang memiliki jumlah PMKS yang cukup banyak. Hingga tahun 2018, jumlah PMKS meningkat setiap tahunnya. Menurut data dari Bapedda Jogjaprov, jumlah PMKS pada tahun 2018 mencapai 659.848 orang. Salah satu PMKS yang memiliki jumlah cukup tinggi yaitu wanita rawan sosial ekonomi (WRSE). Pada tahun 2018, jumlah WRSE meningkat dari tahun sebelumnya yaitu 12.405 menjadi 12.454 orang.

Menurut Permensos RI No 08 tahun 2012 tentang Pedoman Pendataan dan Pengelolaan Data Penyandang Masalah Kesejahteraan Sosial (PMKS) dan Potensi Sumber Kesejahteraan Sosial mendefinisikan WRSE sebagai seorang perempuan dewasa menikah, belum menikah atau janda dan tidak mempunyai penghasilan cukup untuk dapat memenuhi kebutuhan pokok sehari-hari. Banyak faktor yang menyebabkan wanita menjadi WRSE diantaranya yaitu wanita dengan latar belakang keluarga ekonomi miskin, tingkat pendidikan yang rendah sehingga tidak memiliki keterampilan yang memadai, wanita tidak bekerja, dan pendapatan yang tidak mencukupi kebutuhan hidupnya. Banyaknya jumlah WRSE tersebut tentunya membutuhkan suatu usaha yang terarah, terpadu dan berkelanjutan baik itu dilakukan oleh pemerintah pusat, pemerintah daerah, maupun masyarakat dalam bentuk 
pelayanan sosial untuk menangani permasalahan WRSE. Dengan adanya perkembangan zaman dan semakin kompleksnya kebutuhan masyarakat, menyebabkan munculnya organisasiorganisasi sosial yang turut berpartisipasi dalam penanganan dan penyelenggaraan kesejahteraan sosial. Organisasi yang ada di Indonesia memiliki sumbangsih dalam memberikan pelayanan sosial bagi masyarakat.

Pemerintah baik itu pusat maupun daerah bahkan memiliki organisasiorganisasi formal yang sengaja didirikan untuk membantu dalam meningkatkan kesejahteraan sosial dan menyelesaikan permasalahan yang dimiliki oleh masyarakat. Salah satu organisasi milik pemerintah yaitu instansi sosial. Dinas Sosial Daerah Istimewa Yogyakarta merupakan salah satu instansi sosial yang ada di wilayah pemerintah daerah Yogyakarta. Dinas Sosial Yogyakarta memiliki tugas untuk memberikan pelayanan di bidang kesejahteraan sosial khususnya bagi masyarakat yang berada di wilayah DIY.

Dinas Sosial Yogyakarta memiliki UPTD (Unit Pelaksana Teknis Dinas) salah satunya yaitu Balai Perlindungan dan Rehabilitasi Sosial Wanita (BPRSW) Yogyakarta memiliki peran dalam memberikan perlindungan, pelayanan dan rehabilitasi sosial bagi penyandang masalah kesejahteraan sosial khususnya yaitu wanita. Wanita yang mendapat pelayanan di
BPRSW Yogyakarta salah satunya yaitu WRSE. Dalam balai tersebut, WRSE akan mendapatkan treatment dan pelayanan yang sedemikian rupa dengan tujuan untuk mengentaskan WRSE dari masalah kesejahteraan sosial. WRSE dirasa cukup menarik untuk dikaji lebih dalam karena peneliti melihat bahwa saat ini masih terdapat banyak wanita yang belum mampu mencapai tingkat kesejahteraan. Sedangkan alasan peneliti memilih Balai Perlindungan dan Rehabilitasi Sosial Wanita (BPRSW) Yogyakarta sebagai lokasi penelitian yaitu karena balai tersebut merupakan salah satu tempat yang memberikan penanganan bagi WRSE yang berlokasi di Yogyakarta dan BPRSW Yogyakarta juga cukup responsive dalam memberikan pelayanan bagi wanita-wanita PMKS salah satunya yaitu WRSE. Maka dari itu, peneliti ingin mengkaji secara lebih mendalam mengenai peran dari BPRSW Yogyakarta dalam menangani WRSE.

\section{Metode}

Penelitian ini menggunakan metode penelitian kualitatif dengan pendekatan dekriptif. Penelitian deskriptif bertujuan untuk mengumpulkan seluruh informasi mengenai gejala-gejala dan fenomena yang ada, dimana keadaan gejala tersebut berdasarkan atas kondisi apa adanya saat melakukan penelitian (Suharsimi, 2002:234). Lokasi penelitian yang digunakan sebagai obyek penelitian berlokasi di Balai Perlindungan dan Rehabilitasi Sosial Wanita (BPRSW) 
Yogyakarta. Balai ini beralamat di Dusun Cokrobedog, Sidoarum, Godean, DIY. Peneliti memilih lokasi tersebut karena BPRSW merupakan salah satu balai di Yogyakarta yang menangani WRSE.

Penelitian ini dilakukan selama 3 bulan terhitung dari Bulan Februari - April 2019. Pemilihan subjek penelitian dilakukan dengan menggunakan teknik purposive sampling. Subjek penelitian yang dipilih yaitu Kepala BPRSW Yogyakarta, Kepala Seksi Perlindungan dan Rehabilitasi Sosial, pekerja sosial, instruktur keterampilan dan WRSE. Adapun teknik pengumpulan data dalam penelitian ini dilakukan dengan wawancara, observasi, dan dokumentasi. Dalam penelitian ini, teknik analisis data menggunakan model analisis interaktif Miles dan Huberman yang terdiri dari tahap pengumpulan data, reduksi data, penyajian data dan penarikan kesimpulan.

\section{Hasil dan Pembahasan}

Peran Balai Perlindungan dan Rehabilitasi Sosial Wanita (BPRSW) Yogyakarta dalam Menangani Wanita Rawan Sosial Ekonomi

BPRSW Yogyakarta merupakan salah satu lembaga sosial kemasyarakatan yang berbentuk balai atau panti sosial di Daerah Istimewa Yogyakarta. BPRSW Yogyakarta memiliki peran dalam mengentaskan wanita-wanita rawan sosial psikologis salah satunya yaitu WRSE. WRSE dapat dikategorikan sebagai individu yang mengalami kerentanan sosial ekonomi dalam kehidupannya. WRSE terjadi sebagai salah satu perwujudan sebuah risiko yang didapatkan karena gagal dalam beradaptasi dan menghadapi berbagai gangguan. Gangguan yang paling mendasar disebabkan karena faktor ekonomi yaitu kemiskinan. Dari gangguan tersebut kemudian menyebabkan timbulnya gangguan lainnya yaitu rendahnya tingkat pendidikan dan juga terbatasnya keterampilan atau skill yang dimiliki. Neil Adger (dalam Agustian, 2018: 17) menjelaskan bahwa kerentanan merupakan keadaan berisiko terhadap hal yang merugikan serta berhubungan dengan perubahan lingkungan dan sosial yang disebabkan karena tidak adanya kemampuan untuk beradaptasi.

$$
\text { Kegagalan wanita dalam }
$$

menghadapi gangguan seperti kemiskinan, tingkat pendidikan yang rendah dan juga terbatasnya keterampilan yang mereka miliki menuntun wanita menjadi WRSE. Wanita yang sebelumnya memiliki latar belakang ekonomi yang miskin karena gagal dalam beradaptasi justru akan terjatuh kedalam jurang kemiskinan untuk kedua kalinya. Semakin miskin seseorang maka mereka akan semakin rentan untuk mengalami kerentanan sosial ekonomi. Hal ini seperti yang dijelaskan Antonio (dalam Agustian, 2018:19) bahwa kerentanan sosial ekonomi sering dihadapi oleh orang miskin.

Kerentanan sosial ekonomi tidak dapat benar-benar dihilangkan namun dapat dikurangi dengan beberapa usaha yang dilakukan baik dari individu, keluarga, 
masyarakat ataupun institusi sosial. BPRSW Yogyakarta tergolong lembaga sosial yang turut berkontribusi dalam mengurangi risiko dari adanya kerentanan sosial ekonomi. BPRSW Yogyakarta memiliki peran dalam mengentaskan WRSE sehingga mereka mampu melaksanakan fungsi sosialnya seperti sediakala.

BPRSW Yogyakarta juga berperan untuk mempersiapkan WRSE agar lebih mandiri dan memiliki perilaku serta mental yang kuat. Dalam menangani WRSE, BPRSW Yogyakarta memiliki jangka waktu pelayanan yaitu maksimal satu tahun. Meskipun begitu, tidak menutup kemungkinan bahwa waktu pelayanan yang diberikan melebihi batas waktu yang ada karena lama atau tidaknya WRSE mendapatkan penanganan disesuaikan dengan perkembangan yang mereka alami.

Peran BPRSW Yogyakarta dalam menangani WRSE dilakukan dengan memberikan perlindungan sosial dan rehabilitasi sosial. Pelaksanaan program perlindungan dan rehabilitasi sosial sebagai wujud peran dari BPRSW Yogyakarta dalam menangani WRSE dilaksanakan oleh orangorang yang menempati posisi jabatan di balai diantaranya yaitu Kepala BPRSW Yogyakarta, Kepala Seksi Perlindungan dan Rehabilitasi Sosial, pekerja sosial, instruktur keterampilan dan individu lainnya yang berkaitan dengan program penanganan.

Setiap individu yang menempati jabatan di BPRSW Yogyakarta dalam melaksanakan perannya sesuai dengan status jabatan yang mereka miliki. Pelaksanaan peran individu-individu di BPRSW Yogyakarta dapat dianalisis dengan teori peran organisasi. Biddle (1986:73) mengungkapkan bahwa teori peran organisasi fokus pada cara individu menerima dan melakukan serangkaian peran dalam sistem berorientasi tugas dan hierarkis. Dalam lingkungan BPRSW Yogyakarta, masing-masing individu yang memegang jabatan akan memiliki uraian tugas setelah mereka menempati jabatan di BPRSW Yogyakarta. Tugas-tugas tersebut merupakan serangkaian kegiatan yang harus dilakukan sehingga tujuan dari BPRSW Yogyakarta dapat tercapai. Uraian tugas tersebut sebenarnya juga merupakan patokan atau pedoman bagi para pekerja untuk melaksanakan perannya. Jadi mereka dalam melaksanakan perannya sesuai dengan tugas dan fungsi masing-masing. Dalam konteks organisasi, perilaku peran adalah pola tindakan yang berulang yang dianggap penting untuk fungsi yang efektif dalam peran tertentu dan dalam organisasi tertentu (dalam Biddle, 1986).

Berikut ini merupakan penjelasan mengenai wujud peran BPRSW Yogyakarta dalam menangani WRSE:

\section{A. Peran Perlindungan Sosial}

Perlindungan sosial sangat dibutuhkan WRSE sehingga mereka merasa aman dari kondisi yang merugikan diri mereka. Peran dalam perlindungan sosial salah satunya berkaitan dengan kunjungan. BPRSW Yogyakarta berusaha menjauhkan 
WRSE dari pihak-pihak yang dirasa merugikan bagi diri mereka. Oleh karena itu, BPRSW Yogyakarta senantiasa mempertimbangkan siapa saja yang boleh berkunjung, membatasi jam kunjung dan menentukan tempat kunjung. Selain itu, wujud peran dalam perlindungan sosial juga dilakukan dengan melakukan kontrol dalam penggunaan HP dan memberikan jaminan akan kerahasiaan identitas WRSE.

\section{B. Peran Rehabilitasi Sosial}

Rehabilitasi sosial bertujuan untuk memperbaiki atau memulihkan kondisi fisik, mental, dan sosial WRSE sehingga dapat kembali melaksanakan fungsi sosial dalam masyarakat seperti sediakala. Peran dalam rehabilitasi sosial diwujudkan dalam beberapa program sebagai berikut:

\section{Bimbingan Fisik}

Bimbingan fisik diberikan dengan tujuan untuk memelihara dan meningkatkan kesehatan jasmani dari WRSE sehingga mereka mampu untuk menjaga kesehatan tubuhnya.

Bimbingan fisik diwujudkan dalam kegiatan senam SKJ, penyuluhan kesehatan dan cek kesehatan gratis yang dilakukan oleh puskesmas Godean, serta penyuluhan mengenai kesehatan alat reproduksi.

\section{Bimbingan Mental}

Bimbingan mental dilakukan dengan tujuan untuk memperbaiki mental maupun sikap WRSE sehingga mereka memiliki mental yang kuat dan dapat berperilaku sesuai dengan nilai dan norma yang ada. Bimbingan mental diwujudkan dalam pendalaman agama, layanan konsultasi psikologis, penguatan budi pekerti dan pendampingan oleh pekerja sosial.

3. Bimbingan Sosial

Bimbingan sosial diberikan dengan tujuan untuk meningkatkan kepekaan dan kepedulian WRSE terhadap realitas yang ada dalam masyarakat sehingga ketika sudah kembali ke masyarakat dapat berinteraksi dengan baik. Bentuk bimbingan sosial yaitu penyuluhan mengenai kedisiplinan dan kesadaran hukum, pembelajaran mengenai dinamika kelompok, pembelajaran bahasa Jawa, bahasa Inggris, bimbingan seni musik atau suara, kesenian karawitan dan seni tari.

4. Bimbingan Keterampilan

Bimbingan keterampilan diberikan dengan tujuan untuk membekali WRSE dengan keahlian dan keterampilan tertentu. Bimbingan keterampilan diantaranya yaitu bimbingan keterampilan batik, keterampilan jahit, keterampilan salon dan keterampilan olahan pangan.

Setelah mengikuti bimbingan fisik, mental, sosial, dan keterampilan selama 12 bulan dan dinyatakan sudah mengalami perkembangan yang baik maka WRSE selanjutnya akan mengikuti PBK (Praktik Belajar Kerja). PBK dilaksanakan selama kurang lebih 25 hari. Setelah selesai mengikuti PBK, WRSE dinyatakan lulus dari BPRSW Yogyakarta.

5. Bimbingan Lanjut

Program bimbingan lanjut diperuntukkan bagi alumni BPRSW Yogyakarta. Setelah 
menjadi alumni, selang setengah tahun pekerja sosial akan memantau WRSE untuk melihat apakah mereka masih konsen bekerja sesuai bidang keterampilan yang dipelajari selama di BPRSW Yogyakarta ataukah tidak. WRSE yang masih konsen bekerja sesuai bidang akan diseleksi dan dipanggil untuk mengikuti program sertifikasi selama 25 hari. Setelah selesai mengikuti program sertifikasi, WRSE akan mendapatkan sertifikat kerja dan mendapatkan bantuan berupa alat-alat sesuai dengan keterampilan yang mereka ikuti.

Faktor Pendorong dan Faktor Penghambat dalam Menangani Wanita Rawan Sosial Ekonomi

a. Faktor Pendorong

Faktor pendorong merupakan suatu kondisi yang dapat mendukung BPRSW Yogyakarta dalam pelaksanaan perannya untuk menangani WRSE.

1. Sarana Prasarana yang Memadai

Sarana prasarana merupakan komponen yang dapat menunjang dan mendukung pelaksanaan suatu program. Sarana prasarana yang berupa peralatan, benda maupun gedung yang ada di BPRSW Yogyakarta sudah memadai. Sarana prasarana tersebut cukup mendukung pelaksanaan program baik itu bimbingan fisik, sosial, mental maupun keterampilan. Ketika bahan atau perlengkapan yang digunakan dalam bimbingan keterampilan habis, BPRSW Yogyakarta selalu berusaha untuk menyediakan lagi.

2. Kinerja Pekerja Sosial yang Baik

Pekerja sosial memegang peranan penting bagi BPRSW dalam pelaksanaan perannya untuk menangani WRSE. Pekerja sosial merupakan sosok yang paling berperan dan paling dekat dengan WRSE. Kinerja pekerja sosial yang ada di BPRSW Yogyakarta cukup baik sebab pekerja sosial sudah mampu melaksanakan tugasnya dengan baik. Pekerja sosial telah menjalankan perannya sesuai dengan tugas yang diberikan oleh BPRSW Yogyakarta. Selain itu, kerjasama antar pekerja sosial terjalin dengan cukup erat sehingga ketika terdapat pekerjaan yang tidak dapat dilakukan oleh salah seorang pekerja sosial maka pekerja sosial yang lain akan berusaha untuk menggantikannya. Pekerja sosial juga senantiasa bekerja sama ketika terdapat pekerjaan yang memang tidak bisa ditangani oleh satu pekerja sosial saja.

3. Adanya Kerjasama dengan Instansi Lain

BPRSW Yogyakarta melakukan kerja sama dengan lembaga maupun intansi lainnya guna mendukung pelaksanaan program kegiatan sehingga tujuan yang dimiliki dapat tercapai. Kerjasama yang dilakukan dimulai sejak awal penerimaan WRSE menjadi warga binaan di BPRSW Yogyakarta. Dalam pelaksanaan bimbingan keterampilan, BPRSW Yogyakarta menjalin kerjasama 
terkait instruktur keterampilan. Selain itu, BPRSW Yogyakarta juga melakukan kerjasama dengan beberapa perusahaan guna mendukung pelaksanaan program PBK dan sertifikasi.

b. Faktor Penghambat

Faktor penghambat merupakan suatu kondisi atau keadaan yang dapat menghalangi maupun merintangi BPRSW Yogyakarta dalam melaksanakan perannya untuk menangani WRSE.

1. Terbatasnya Jumlah Anggaran Jumlah anggaran BPRSW Yogyakarta cukup terbatas. Hal itu karena sumber anggaran BPRSW Yogyakarta hanya berasal dari APBD DIY yang mana jumlahnya juga terbatas. Terlebih lagi, BPRSW Yogyakarta tidak memungut biaya sepeserpun dari WRSE yang mendapatkan penanganan. Terbatasnya jumlah anggaran berimbas pada terhambatnya peningkatan sarana prasarana dan juga pemenuhan kebutuhan lainnya.

\section{Kurangnya Jumlah Pekerja Sosial}

Jumlah pekerja sosial tidak sebanding dengan jumlah keseluruhan klien yang harus ditangani oleh BPRSW Yogyakarta. Saat ini hanya terdapat empat pekerja sosial sedangkan jumlah keseluruhan klien sebanyak 60 orang. Apabila dihitung, satu pekerja sosial memiliki anak asuh 15 orang. Jumlah tersebut tidak ideal karena menurut
Kemensos satu pekerja sosial hanya memiliki anak asuh 5 orang saja. Selain itu jumlah pekerja sosial laki-laki yaitu 3 orang sedangkan pekerja sosial wanita hanya 1 orang. Sementara, sasaran BPRSW Yogyakarta yaitu wanita yang mengalami permasalahan sosial. Pekerja sosial laki-laki tidak bisa secara intens memberikan dampingan maupun penanganan khususnya yang berhubungan dengan masalah kewanitaan. Sebab tingkat pengetahuan mengenai kewanitaan antara pekerja sosial laki-laki dengan pekerja sosial wanita akan jauh berbeda. Pekerja sosial laki-laki juga akan merasa canggung ketika menanyakan hal-hal yang berkaitan dengan kewanitaan.

3. Kurangnya Minat dan Konsentrasi WRSE.

Kurangnya konsentrasi WRSE ketika mengikuti kegiatan salah satunya karena klien tersebut memiliki anak yang masih bayi. Jadi konsentrasi mereka terpecah menjadi dua antara mengasuh anak dan mengikuti kegiatan. Selain itu, tingkat permasalahan yang dimiliki WRSE turut mempengaruhi tingkat konsentrasi mereka. WRSE yang memilki tingkat permasalahan yang berat maka dirinya akan kesulitan untuk berkonsentrasi. Sementara itu, kurangnya minat WRSE disebabkan karena keberadaan mereka di BPRSW Yogyakarta bukan karena kemauan sendiri melainkan hasil rujukan keluarga 
maupun masyarakat. Jadi ada rasa terpaksa ketika berada di BPRSW Yogyakarta.

4. WRSE Memiliki Suasana Hati yang Tidak Stabil

Suasana hati yang tidak stabil menyebabkan emosi WRSE naik turun dan cenderung sensitif. Ketika suasana hati WRSE sedang tidak baik, mereka cenderung malas untuk mengikuti program kegiatan terutama bimbingan keterampilan. Selain itu, suasana hati WRSE yang tidak stabil menyebabkan mereka memiliki emosi yang tinggi. Ketika emosi WRSE memuncak, terkadang mereka melampiaskannya dengan cara merusak fasilitas yang ada. Beberapa WRSE terkadang juga salah mengartikan perhatian yang diberikan oleh pekerja sosial. WRSE beranggapan bahwa pekerja sosial tersebut jatuh hati kepada mereka. Hal itu tentu menyebakan pekerja sosial laki-laki sedikit menjaga jarak dengan WRSE sehingga penanganan yang diberikan menjadi kurang maksimal.

5. Kurangnya Dukungan dari Keluarga dan Masyarakat

Beberapa pihak keluarga dari WRSE kurang memberikan dukungan ketika salah satu anggota keluarganya ditangani di BPRSW Yogyakarta. Keluarga cenderung acuh tak acuh dengan keadaan anggota keluarga. Dengan tidak adanya dukungan dari keluarga maka menyebabkan WRSE merasa bahwa mereka tidak diperhatikan dan dihargai oleh keluarganya. Mereka merasa bahwa usaha mereka untuk pulih hanya sia-sia karena keluarga tidak mendukung mereka untuk sembuh.

Selain itu, masyarakat juga kurang peduli dengan keberadaan anggota masyarakat yang mengalami permasalahan sosial dan cenderung menutup-nutupi sebab dianggap sebagai aib dalam masyarakatnya. Hal tersebut menyebabkan BPRSW Yogyakarta tidak dapat melakukan penjangkauan secara maksimal sebab datadata wanita yang mengalami permasalahan sosial tidak dapat diketahui dengan sebenarbenarnya. Kondisi tersebut tentu menjadi penghambat BPRSW Yogyakarta dalam menangani WRSE.

\section{Simpulan}

Peran BPRSW Yogyakarta dalam menangani WRSE dilakukan dengan memberikan perlindungan sosial dan rehabilitasi sosial. Peran BPRSW Yogyakarta dalam perlindungan sosial dilakukan dengan menentukan siapa saja yang boleh berkunjung, membatasi jam kunjung, menentukan tempat kunjung, kontrol dalam penggunaan HP dan jaminan akan kerahasiaan identitas WRSE. Sedangkan peran BPRSW Yogyakarta dalam rehabitasi sosial dilakukan dengan memberikan beberapa program bimbingan diantaranya yaitu bimbingan fisik, mental, sosial dan keterampilan.

Setelah WRSE dinyatakan kuat secara 
fisik, mental dan keterampilan maka selanjutnya mereka akan mengikuti PBK (Praktik Belajar Kerja) selama 25 hari. WRSE akan diterjunkan langsung ke lapangan untuk bekerja di beberapa tempat usaha sesuai dengan keterampilan yang mereka ikuti. WRSE yang telah melaksanakan PBK dianggap lulus dan menjadi alumni BPRSW Yogyakarta. BPRSW Yogyakarta juga memiliki program bimbingan lanjut bagi alumni yang masih konsen bekerja sesuai bidang keterampilannya yaitu program sertifikasi.

Setelah mengikuti program sertifikasi, WRSE akan mendapatkan sertifikat kerja dan bantuan berupa satu set peralatan sesuai bidang keterampilan masing-masing.

Faktor pendorong dalam menangani WRSE diantaranya yaitu adanya sarana prasarana yang memadai, kinerja pekerja sosial yang baik dan adanya kerjasama dengan instansi lainnya. Sedangkan faktor penghambatnya yaitu terbatasnya jumlah anggaran, kurangnya jumlah pekerja sosial, kurangnya minat dan konsentrasi WRSE, WRSE memiliki suasana hati yang tidak stabil dan kurangnya dukungan dari keluarga dan masyarakat.

\section{Ucapan Terimakasih}

Terimakasih disampaikan kepada semua pihak yang telah mendukung dalam penulisan ini sehingga terlaksana dengan baik dan tim redaksi Jurnal Dimensia yang telah mempublikasikan hasil karya tulisan ini.

\section{Daftar Pustaka}

Peran Balai Perlindungan Wanita dan Rehabilitasi Sosial Wanita (BPRSW) Yogyakarta Dalam Menangani Wanita Rawan Sosial Ekonomi | Noor Yuli Astuti, Poerwanti Hadi Pratiwi, Aris
Agustian, Reza. (2018). Kerentanan Sosial Ekonomi Vulnerability) Pedagang Kaki Lima Pasca Relokasi (Studi Kasus: Abang Blok G). Skripsi S1. Jakarta: Universitas Islam Negeri Syarif Hidayatullah.

Biddle, B.J. (1986). Recent Developments in Role Theory, Annual Review of Sociology, Vol 12: 67-92.

Permensos. (2012). Peraturan Menteri

Sosial RI Nomor 08 tahun 2012 tentang Pedoman Pendataan dan Pengelolaan Data Penyandang Masalah Kesejahteraan Sosial (PMKS) dan Potensi Sumber Kesejahteraan Sosial.

Presiden RI. (2009). Undang-Undang Republik Indonesia Nomor 11 Tahun 2009 tentang Kesejahteraan Sosial.

Suharsimi, A. (2002). Prosedur Penelitian Suatu Pendekatan Praktek. Jakarta: PT Rineka Cipta.

Undang-Undang Republik Indonesia Nomor 11 Tahun 2009 tentang Kesejahteraan Sosial. (Socio-Economic Pedagang Kaki Lima Pasar Tanah 